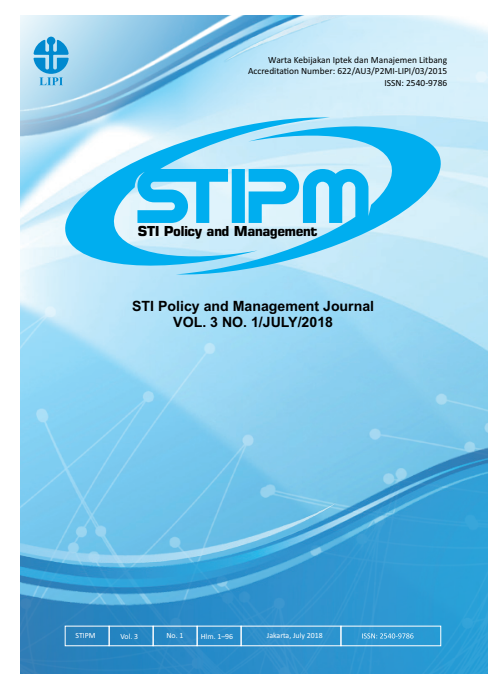

Journal of STI Policy and Management

Publication details, including instructions for authors and subscription information: http://www.stipmjournal.org/

\title{
Theoretical and Practical Gaps in Policy Making Process in Five Organizations
}

\author{
Nor Ashikin Mohamed Yusof, Sri Widias Asnam, Aini Suzila Anas, \\ Nur Suraya Mustapha, Natrah Emran, Nor Azalina Azman \\ ${ }^{1}$ UTM Perdana Sekolah Polisi Sains, Teknologi \& Inovasi \\ Universiti Teknologi Malaysia, MALAYSIA \\ 2,3,4,5,6 Malaysian Industry-Government Group For High Technology \\ Jalan Impact, 63000 Cyberjaya, Malaysia \\ Version of record first published: 15 July 2019
}

To cite this article: Yusof, N. A. M., Asnam, S. W., Anas, A. S., Mustapha, N. S., Emran, N., Azman, N. A. (2019). Theoretical and Practical Gaps in Policy Making Process in Five Organizations. Journal of STI Policy and Management, 4(1), 35-42

To link to this article: http://dx.doi.org/10.14203/STIPM.2019.157

ISSN 2540-9786 (Print); ISSN 2502-5996 (online)

Accreditation Number: 21/E/KPT/2018

Full terms and conditions of use: https://creativecommons.org/licenses/by-nc-sa/4.0/

You are free to:

- Share : copy and redistribute the material in any medium or format

- Adapt : remix, transform, and build upon the material

- The licensor cannot revoke these freedoms as long as you follow the license terms.

Under the following terms:

Attribution - You must give appropriate credit, provide a link to the license, and indicate if changes were made. You may do so in any reasonable manner, but not in any way that suggests the licensor endorses you or your use.

$\$$ NonCommercial - You may not use the material for commercial purposes.

(3) ShareAlike - If you remix, transform, or build upon the material, you must distribute your contributions under the same license as the original.

No additional restrictions - You may not apply legal terms or technological measures that legally restrict others from doing anything the license permits.

Notices:

- You do not have to comply with the license for elements of the material in the public domain or where your use is permitted by an applicable exception or limitation.

- No warranties are given. The license may not give you all of the permissions necessary for your intended use. For example, other rights such as publicity, privacy, or moral rights may limit how you use the material.

- If you copy the dataset merely to extract the uncopyrightable data elements would not need permission to do so. However, if you republish the full dataset or using the copyrightable data layers require a permission from PAPPIPTEK-LIPI. 


\title{
JOURNAL OF SCIENCE, TECHNOLOGY AND INNOVATION POLICY AND MANAGEMENT (STIPM JOURNAL), Volume 04, Issue 01, July 2019
}

\author{
FOREWORD by EDITOR-in-CHIEF
}

We are very pleased to inform the readers that Journal of Science, Technology, \& Innovation Policy and Management (STIPM Journal) Vol. 4, No. 1, July 2019 edition is now ready for public reading and views. STIPM Journal is an online research journal managed by the Research Center for Science, Technology, and Innovation Policy and Management, Indonesian Institute of Sciences (RC-STIPM-LIPI).

The journal provides scientific information that needed mostly by the research scholars as well as STI policy makers. As a peer reviewed journal, STIPM provides free access to research thoughts, innovation, and original discoveries. In this issue, we bring together research findings on development and adoptation of science, technology, and innovation policy and management from Malaysia and Indonesia.

First article is composed by Wati HERMAWATI entitled Technology Transfer from Public Research Institute to Community: A Case Study. This research article examines the technology transfer mechanisms into practical applications of the community. The success of technology transfer to community itself were demonstrated by the increased ability of recipients namely SMEs and farmers to replicate the technologies, increased their production, enlarge their market as well as increased new knowledge, skills, and productivity.

Second research article entitled A Scientometric Study on Biodiesel Development in Indonesia. This article is presented by Mesnan SILALAHI et al. The article describes the results of scientometric studies in the energy sector, especially in the field of biodiesel in Indonesia by using a mixed method through content analysis and in-depth interview. Quantitative research uses bibliometric basics and content analysis, where text mining is triangulated with the results from in-depth interview with several prominent Indonesian researchers in this field. Content analysis is conducted by topic modeling method by analysing the papers' abstract. This article reports on the results of a scientometric study, based on publications indexed in Scopus in the energy sector, especially in the field of biodiesel in Indonesia.

Nor Ashikin Mohamed YUSOF et al. present an article entitled Theoretical and Practical Gaps in Policy Making Process in Five Organizations. This article reports case studies involving five national policy documents and internal policies at several key governmental department and organizations. The findings from the study enables the researchers to make a comparison between the theory of policy making and the practice of policy making in Malaysia. The findings show that there is still a huge gap between theory and practice in policy making and policy studies in Malaysia.

The fourth article with the title Innovative Strategy to Disseminate Science Information to Policy makers is presented by Azmi HASSAN. There exists a huge gap between science and technology discovery and the formulation of public policy mostly due to the poor understanding on how to disseminate the 
news not only to policy makers but also to the general public. To bring accurate, relevant information from the front lines of research to the policy makers, this paper describes how innovative strategies that use the media as the conduit are formulated in more systematic ways.

Dian KUSUMANINGRUM et al. present an article entitled Structural Equation Model: Intention to Use Mobile Banking of Bottom of Pyramid Customer. The purposes of the study are to identify the predicting factors influencing the intention to use mobile banking and empirically validate a model explaining the behavioral intention to use it, especially on the bottom of pyramid (BOP) segment. The model used was structural equation model (SEM) based on partial least square (PLS). The data used for developing the model was based on a survey to 100 BOP households. The results show that the variables that have the highest significant effect on BOP's customer intention to use mobile banking are involuntary barriers, followed by perceived risk, and attitude. This result can be further used by researchers and mobile banking providers to evaluate the existing mobile banking services to improve its contribution in providing better market penetration and more appropriate financial services for BOP and ultimately financial inclusion in Indonesia.

Lastly, Karlina SARI et al. present an article entitled Indonesia in Functional Food Industry: Market or Player? This paper presents the overview of functional food industry in Indonesia. It analyzes the prospect of Indonesian functional food industry from demand, supply, and regulation perspective. The result of this study is Indonesia should have a good prospect as both the market and the player in functional food industry. Currently, baby food and toddler are Indonesia's biggest market of functional food for baby formula milk and baby food. Another functional food market segment prospective to be penetrated is elderly who have bigger risk of disease, such as hypertension and arthritis

The journal is indexed by Google Scholar, ISJD, IPI, DOAJ, BASE, and OCLC World Cat, which makes wider journal dissemination. We would like to express our immense gratitude to our international editorial board members, reviewers, and authors for their contribution to this issue. We hope this publication will prove useful for readers and contribute to the enhancement of science, technology, and innovation. We expect that STIPM will always provide a higher scientific platform for authors and readers with a comprehensive overview of the most recent STI Policy and Management research and development at the national, regional, dan international level.

Jakarta, July 2019

Editor-In-Chief 



\section{JOURNAL OF STI POLICY AND MANAGEMENT}

Volume 4, Number 1, July 2019

\section{LIST OF CONTENTS}

Technology Transfer from Public Research Institute to Community: A Case Study

Wati Hermawati..

Scientometric Study on Biodiesel Development in Indonesia

Mesnan Silalahi, Agus Santoso dan Dudi Hidayat.

Theoretical and Practical Gaps in Policy Making Process in Five Organizations

Nor Ashikin Mohamed Yusof, Sri Widias Asnam, Aini Suzila Anas, Nur Suraya Mustapha,

Natrah Emran, Nor Azalina Azman

Innovative Strategy to Disseminate Science Information to Policy Makers

Azmi Hassan

Bottom of Pyramid Customer Intention to Use Mobile Banking: Structural Equation Model

Dian Kusumaningrum, Dewi Saraswati, Seprianus.

Drivers of Industry Convergence: The Case of Functional Food Industry in Indonesia

Karlina Sari, Dian Prihadyanti, Dudi Hidayat 


\title{
(i) STI POLICY AND MANAGEMENT
}

\section{Theoretical and Practical Gaps in Policy Making Process in Five Organizations}

\author{
Nor Ashikin Mohamed Yusof ${ }^{1}$, Sri Widias Asnam² ${ }^{2}$, Aini Suzila Anas ${ }^{3}$, Nur Suraya Mustapha ${ }^{4}$, \\ Natrah Emran ${ }^{5}$, Nor Azalina Azman ${ }^{6}$
}

${ }^{1}$ UTM Perdana Sekolah Polisi Sains, Teknologi \& Inovasi

Universiti Teknologi Malaysia, MALAYSIA

ashikin.kl@utm.my

2,3,4,5,6 Malaysian Industry-Government Group For High Technology

sriwidias@might.org.my²,anisuzi@might.org.my ${ }^{3}$ suraya@might.org.my4, natrah@might.org.my ${ }^{5}$,azlina@might.org.my ${ }^{6}$

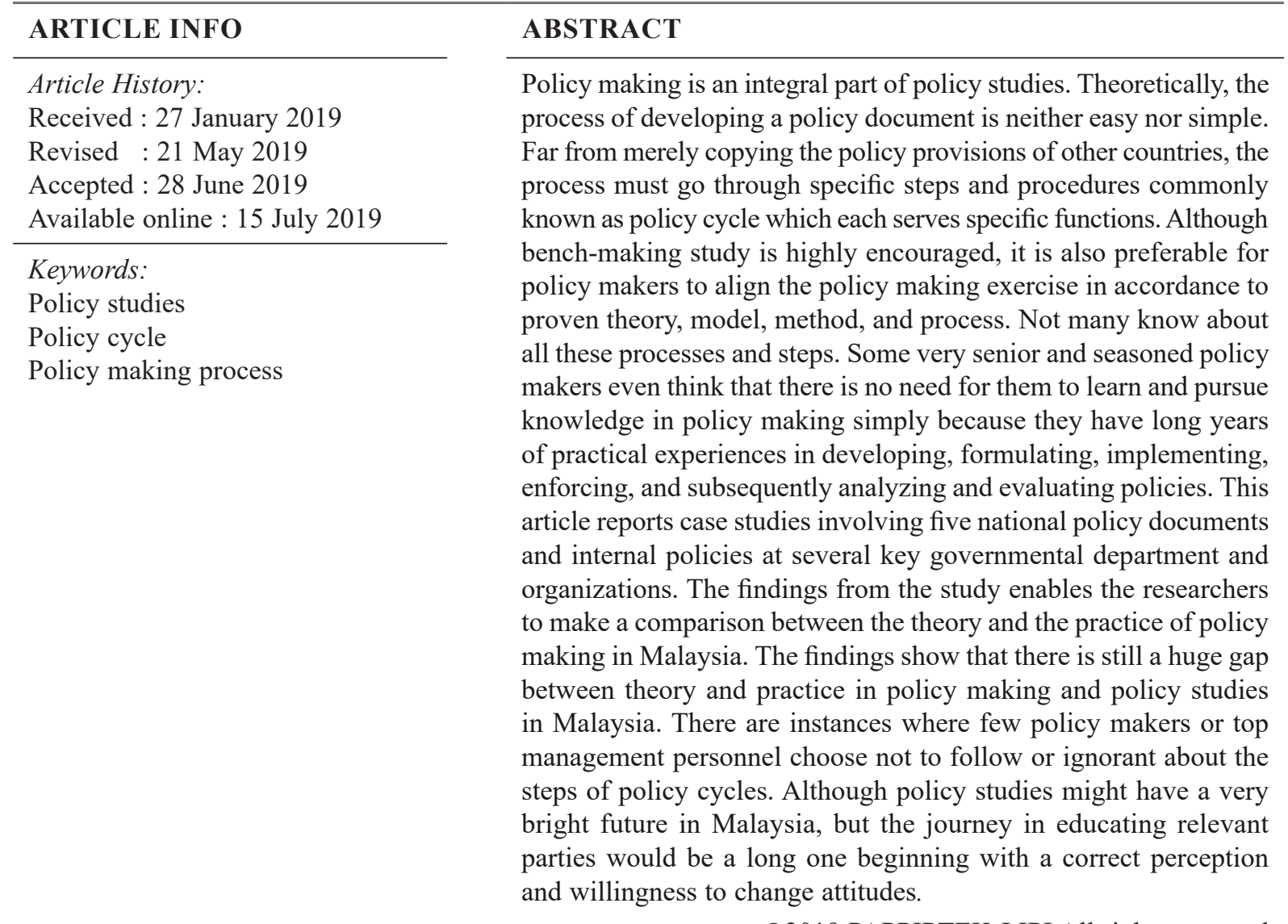




\section{A. INTRODUCTION}

The crucial roles of science, technology and innovation (STI), and policy in socio-economic growth are well demonstrated by the success stories of developed nations. South Korea and Japan, for example, are nations with scarce natural resources, yet remain as economic giants internationally. There is no secret recipe for their success, except their willingness to develop and use STI and policy as tools for economic development. The use of science, technology, and innovations in developing and bringing national economic transformation need no mentioning, but the function of policy could and should not be underestimated either. Only policy could bind these developmental tools together and strategically translate them into action plans and programs for economic transformation and development.

The old approach of policy making in importing or tinkering with the provisions of foreign policy before adopting them to local requirements are over. Although not wrong, the decision to develop a policy based on peers and their past actions or practical experiences of others alone might not necessarily bear the desired fruits. A policy must be reflective of local technological capabilities, economic resources, cultures, and contexts in overcoming the domestic problems of a nation. Otherwise, such policies would face implementation difficulties and enforcement issues. Policy must be meaningful, do-able, and achieve-able.

Policy studies are relatively new field of study in Malaysia. This can be seen through lack of policy studies programs at first degree or at postgraduate levels of local universities, publications or that research on the said subject matters locally. There is a need to study the capability and skills of local policy maker, their policy making process or whether there is any theoretical and practical gaps in those processes.

This report is about the process of policy making in five organizations and its theoretical and practical gaps in the process. The research considers some key questions, e.g. do policy makers consult or invite stakeholders, as industry and academia, for policy inputs in the policy making process? How to start the policy making process? Do policy makers follow the policy cycle in the policy making process properly? Do they have any particular policy model references?

\section{B. ANALYTICAL FRAMEWORK}

A good policy is capable of taking the organization or nation to greater new heights (Gerston, 2010). Without a detailed policy, no goals or objectives of the organization or government could be achieved (Truelove, 1995). The organization or nation would be trapped, stagnant and lag behind, unable to evolve, and keep up with the ever changing times and global scenarios (Ariffin \& Mansor, 2009).

\section{Policy Cycle}

Policy making process refers to the processes of translating political visions into reality through certain strategies and selected programs in bringing benefits to the public at large or solving certain problems (Friedman, 2002). In Malaysia, the policy making process can occur through three channels, (1) political channel, where the policy is initiated through cabinet's orders or through recommendation of several political reigning parties, (2) through administrative channel where it happens at the ministerial level and the drafted policy is discussed at several high-level government meetings, and (3) policy could develop through the combination of process number 1 and 2. Through this integrated approach, the government would set up a special committee and instruct it to study the proposed policy in-depth before presenting it to the cabinet or minister to decide and assign the matters to relevant ministry or departments (Muslihah, 2010). In most cases, Malaysian policy has been designed generally on the requirements of the political and social structure, and the future demand of the nation (Ansori, 2013). The New Economic Policy 1970 and Vision 2020 are good examples of the above.

The processes are complex and policy makers obviously need to observe certain procedural steps (Malaysian Framework for Evaluation Policy And Standards [MyFEPS], 2016). Policy design, formulation and development are several of the many crucial components of policy making process (Parsons, 1995). The process may vary 
from country to country. Theoretically, policy making process may proceed in five or six stages (Howlett \& Ramesh, 1995). Policy experts, such as Althaus, Bridgman, and Glyn (2017), has numerously warned that such process is never linear, sequential, and the entire process is in no way automatic. It could start, change directions or even cease at any point (McCool, 1995). It is common in many developing countries where the governments being the policy makers would start or end a policy without conducting needs study or any policy evaluation respectively (Ascher, 2017). Likewise, another policy could be introduced or implemented before it is formally or legally adopted. In many ways, the policy making process depends a lot on the type of political structure and agendas (MyFEPS, 2016).

At all times the policy makers must consciously be aware of diverse influences and constraints on government (Bari, 2009). In setting the agenda of national policy, the purpose and objectives of a policy are often influenced by external factors that happen thousand miles away from homeland. Such a thing is unavoidable since the world has become more globalized. As a diversified nation, policy makers in Malaysia must carefully consider politic, social, economy, moral and religion before formulating, designing and developing a policy in order to make the policy reasonably acceptable to all (MyFEPS, 2016).

\section{Policy Models}

In Malaysian context, the policy making processes are undertaken by public servants within the civil service (Ansori, 2013). Although Malaysia inherited the Westminster administration system from the British government, Malaysian policy makers are slow in following the British or other developed countries in adopting the open-ended and bottom up approaches (Harvman, 1987; Atory, 2008). It is not known whether Malaysian policy makers actively consult academia or society in the policy making process (Atory, 2008). According to Leong (1992), the policy making process is a relatively autonomous administrative act, centralized, and often shrouded in secrecy. Therefore, the top-down approaches are very common. The policy inputs and outputs are mainly and systematically determined by government bureaucrats, limiting the involvement to certain group of top brass and internal officials, before proposals are made known to public for discussion, debate or simply execution.

\section{Policy Approach}

Perhaps, the said approach suits the local context. Malaysians generally still have low exposure to policy making or policy studies (Rahmah, 2004). Society generally assumes the work to design, formulate, and develop policy falls under the jurisdiction of the government and directly unrelated to them (Bingham \& Felbinger, 1989). Some also assume that governments represented by politicians and civil servants as policy makers have the relevant academic knowledge and skills to formulate and develop policy through their respective work experiences (Whoky, 1970).

\section{Policy Engagement}

Whether the above assumption is true, it is not fully known. There is still very few data coming from developing countries on the capabilities and skills of policy makers in designing, formulating and developing a policy. Gicks (2000) commented that developing countries generally lack sound knowledge or exposure on the policy making process. Neither the general public nor policy makers pay attention to whether a policy is formulated, designed or developed based on relevant theory, using specific methods or models as already proven effective in developed countries (Gicks, 2000). As a result, the public or policy makers generally do not place much emphasis on the importance of policy studies, even place less stress on the need to make policies according to the actual theory, processes, policies and rules. Gick's opinion echoes the finding of Whoky's work thirty years earlier. According to Whoky (1970), the phenomenon is widely found in developing countries. In 2004, Rahmah uncovers more or less the reasons for such lack-luster attitude amongst policy makers of developing countries. More seriously, there are some policy makers who do not have or feel the urgent need to learn and 
explore the intricacies of policy making process simply because they already have the practical experience needed to do so (Rahmah, 2004). There are instances when policy makers simply import and tinker the provisions of foreign policy before changing or adopting the said policy for Malaysia (Rahmah, 2004).

Opportunities to study the capability, skills or theoretical and practical gaps in policy making process come in the form of internship program. It is a requirement part of the Masters of Science Technology and Innovation Policy (MSTIP) of UTM Perdana Center of Science Technology and Innovation Policy. The internship program enables students to blend and incorporate all theories learned in classroom with the practical demand of work in real world. In other words, students are expected to put their knowledge into practice, observe, compare, analyze and evaluate the actual situation in the field. Students are free to make informed comments. They are welcome to offer informed suggestions for improvements (Poon, 1994). Cascio (1989) believed that practical exercises can also help and equip students with the soft skills before facing the real world of career challenges.

\section{METHODOLOGY}

The research uses a case study approach where the data will be described qualitatively. The primary data gathered through interviews and observations. This method is suitable when it involves a small group of respondents or specific issues (Yin, 1994) or when there is no previous study of such nature (Churchill, 1991). Description of cumulative data is made deductively and critically based on realistic paradigms (Miles \& Huberman, 1994). Esterberg (2002) also supports the use of such techniques and approaches which advocate text and content analysis. In this case, data are collected by five students of Masters Science Technology and Innovation Policy programs who underwent internship program at five different organizations. The internship program started at February 2016 and ended in May 2016. During their internships, students were assigned to an industrial supervisor(s) who oversaw their activities and progress. Each student was specifically assigned to work with a team that is either in the midst of designing, formulating, developing or evaluating a policy document. Apart from face to face interviews, discussions and observations, this research also used secondary data for comparison purposes.

\section{RESULTS AND DISCUSSION}

\section{Demography}

The data for this report, as shown below, were collected from a series of interviews and observations. They were then divided into several themes, e.g. (1) the type of entity, policy document involved and the stage of policy cycle process, (2) knowledge on the policy cycle process, (3) approach taken by the organization in policy development activities, (4) stakeholders involvement in the policy cycle process, (5) level of involvement in giving policy inputs, (6) point of involvement, and (7) reference to model or the theory. The data revealed gaps between theory and practice in the policy cycle process at the organization level. For the purpose of confidentiality, the name of each organization shall be marked and identified as organizations A, B, C, D and E.

Table 1. Name and Types of Policy Document Understudy

\begin{tabular}{ll}
\hline \multicolumn{1}{c}{ Organization } & \multicolumn{1}{c}{ Policy Understudy } \\
\hline \multirow{2}{*}{ A-Government agency } & $\begin{array}{l}\text { - Offset policy } \\
\text { - National policy }\end{array}$ \\
\hline B-Government agency & $\begin{array}{l}\text { - Shipping carbotage policy } \\
\text { - National policy }\end{array}$ \\
\hline \multirow{2}{*}{ C-Government agency } & - Science to action policy \\
& - Organizational policy \\
\hline & - Intellectual property \\
D-Ministry & - Commercialization policy \\
& - Organizational policy \\
\hline E-Ministry & - High Industry policy \\
& - National policy \\
\hline
\end{tabular}

Table 2. Stage of Policy Cycle

\begin{tabular}{cl}
\hline Organization & \multicolumn{1}{c}{ Policy cycle } \\
\hline A & Implementation (3) \\
\hline B & Agenda setting (1) \\
\hline C & Design \& formulation (2) \\
\hline D & Agenda setting (1) \\
\hline E & Implementation (3)
\end{tabular}


Three of the organizations are dealing with national policy whereas at two other organizations are dealing with organizational policy (Table 1). Regardless whether the policies were for national or organization, they were subjected to the same process of policy making. These organizations are at different stages of the policy cycle process (Table 2).

\section{Practical Gaps}

The data in Table 3 indicated that not all policy makers and top management officers in all organizations involved are fully aware of the concept, process, method or models of policy making process as recommended by theories or academics. The answers of senior and seasoned policy makers at Organization A and B are quite alarming. They openly admitted lack of formal knowledge on policy making process. They however do not see it as a handicap since they have years of previous experience at various other organizations. They feel that such practical experience were able to help them in designing, formulating and developing policy. Such attitude or feeling is not limited to very senior and seasoned policy makers in Organization A or B alone. The same outlook is also displayed by same categories of policy makers at other organizations too. Comparatively the young and mid-management policy makers are more open and wanted to have a chance in studying policy making process formally. On the other hand, policy makers and officers at Organization $\mathrm{C}$ and $\mathrm{D}$ do have the formal knowledge about policy making process. Both gave different reasons for not applying them in practice. Although keen, policy makers at Organization $\mathrm{C}$ are not given the proper opportunity to do so for pressure of time and failure to convince their superiors. Whereas, policy makers and officers at Organization D claimed they lack practice. This

Table 3. Knowledge on Policy Cycle

\begin{tabular}{cl}
\hline Organization & Knowledge on Policy cycle \\
\hline A & None \\
\hline B & None \\
\hline C & Know but does not practice \\
\hline D & Know but do not know how to apply \\
\hline E & Mixed \\
\hline
\end{tabular}

is especially so when their numbers are small. The latter is more dominant and influential in making the decision whether to develop a policy according to policy cycle or otherwise. Not all policy makers and top management officers of organization $\mathrm{E}$ have the formal knowledge about policy making process or policy cycle. They do not apply such knowledge at all times but occasionally only. The decision to follow or not are very much attach to individual and personality.

Table 4. Reference to Theory or Policy Models

\begin{tabular}{cc}
\hline Organization & $\begin{array}{c}\text { Reference to } \\
\text { Theory or Policy Models }\end{array}$ \\
\hline A & Nil \\
\hline B & Nil \\
\hline C & Nil \\
\hline D & Nil \\
\hline E & Nil \\
\hline
\end{tabular}

None of the organizations made any reference to any theory or have any particular policy models in dealing with the policy understudy.

Table 5. Origination of Policy and Approach of Policy

\begin{tabular}{cc}
\hline Organization & Origination of policy and Policy Approach \\
\hline Org. A & Half open, top down \\
\hline Org. B & Half open, top down \\
\hline Org. C & Closed, both ways \\
\hline Org. D & Closed, top down \\
\hline Org. E & Open, top down \\
\hline
\end{tabular}

Organization $\mathrm{C}$ reported that the decision to develop their respective policies were usually based on the instructions from their leaders. Then, they would conduct some small research and benchmark studies before informing their leaders and top management on the needs to develop the understudy policy. However, the final decision to develop, evaluate or review a policy document in Organization $\mathrm{C}$ still remains with their superiors. Organization A and B approached the matter slightly different. The policy makers would only start to consult others, conduct research and needs analysis for the purpose of policy making process upon receiving instruction from their superiors. As explained further below, organization $\mathrm{A}$ and $B$ would when necessary call for the involvement of stakeholder. 
In discharging their duties, the organizations have different approaches. Four of five organizations still prefer the old and conventional ways of policy making. Only organization $\mathrm{E}$ is open and willing to invite stakeholders, such as the public or industry to participate in their policy making process. The stakeholders are needed either in giving data inputs, ideas and comments for improvements. This was followed by Organization $\mathrm{A}$ and $\mathrm{B}$, when they adopted semi-open approaches in their work. In this context, they did not invite stakeholders on a regular basis, but merely when they feel the necessity to do so and subject to budget and time constraints. They did not give further or detailed explanation on what they consider as "necessity". Organization $\mathrm{C}$ and $\mathrm{D}$ were not willing to be open and invite others as part of their policy making process even when the said approach would limit the quality of policy inputs and outputs. No reasons were given for their preferences.

Table 6. Involvement of Third Party

\begin{tabular}{cl}
\hline Organization & Third's party \\
\hline Org. A & Selective \\
\hline Org. B & On needs basis \\
\hline Org. C & Nil \\
\hline Org. D & Nil \\
\hline Org. E & Scheduled \\
\hline
\end{tabular}

Student A finds policy makers at organization A are only willing to selectively call stakeholders in assisting them in the policy making process. The stakeholders are chosen because of their track records in the past or personal or close association within a known organization. Organization A prefers it that way for easy management purposes. Student B reported that Organization B would only call stakeholders on need-only basis. This happens if they want to have some technical advice or endorsement purposes. Organizations $\mathrm{C}$ and $\mathrm{D}$ so far have yet to involve any stakeholders in their policy making process. They are reluctant to do so for fear that stakeholders would deviate their discussions or policy objectives and for lack of time. Organization $\mathrm{E}$ is more structured and organized.

However, there was some agreement on organization involvement with stakeholders.
For example, first, they had set up a timetable and schedule for meetings with the public and relevant stakeholders for a variety of purposes and objectives. Second, they agreed that a special skill that policy makers needed was to communicate, negotiate and convince the stakeholders to agree with proposed policy or policy provisions. Third, the organizations admitted they lacked policy makers who could do the policy advocacy.

Table 7. Point of Involvement

\begin{tabular}{cl}
\hline Organization & Point of Stakeholder Involvement \\
\hline A & Final-Approval \& endorsement \\
\hline B & Final- Approval \& endorsement \\
\hline C & Final- Notification \\
\hline D & Final- Notification \\
\hline E & At all stages \\
\hline
\end{tabular}

Based on their norms and past experiences, the organizations invited stakeholders for policy inputs at different points (Table 7). From their response, there is no active or more meaningful stakeholder engagements at the agenda setting stage since the directions of the policy is predetermined by their superiors. Students A and $\mathrm{B}$ recorded that their organization only call for stakeholders as input providers at the final stages of the relevant policy cycle process. For example, they found them are more interested to get the stakeholders' approval and endorsement of the completed policy document and just before the relevant documents were executed. Organization $\mathrm{C}$ and $\mathrm{D}$ have the most minimum engagement with stakeholders. The stakeholders were called for the purpose of notifying them that the organizations are about to execute a certain policy. Meanwhile, student $\mathrm{E}$ finds the organization appreciates the role and opinions of stakeholders as policy inputs. Right from the start, Organization E had set the schedule in calling stakeholders for discussions. They also claimed that it did take into account the stakeholders input and discussed them internally in the policy process.

Conclusively, the data obtained from the five organizations above revealed that there is a theoretical and practical gap in policy making process in Malaysia. As shown by the data, there was very little improvement or change in policy making process since the last comment and observation 
made by Atory (2008) and Rahmah (2004) on policy making process in Malaysia. The data on origination of policy seems to be in line with what Atory (2008) and Leong (1992) had observed.

The findings above confirm the views of Rahmah (2004) and Bingham and Felbinger (1989). Despite the passing of times, advancement in knowledge, better exposure and availability of various referral materials on policy making process, Malaysians generally have not progressed much in this area. As Bingham and Felbinger highlighted in 1989, the behaviour of Malaysia towards policy making remains the same. Society is still not paying enough attention towards what the policy makers are doing, even though policy would potentially affect their future. Their tendencies in leaving the matter in the hands of government and policy makers are raising concerns.

Secondly, Malaysia, like any developing countries, is quite slow in accepting or adopting the benchmark for policy making process set or as practice by developed countries. Only few have shown the interest to actively consult academia or_society for policy inputs as proposed by Atory (2008) and do it according to the policy cycle. Though quite frustrating, such positive effort deserves an applause.

Admittedly, there are still differences in approaches in policy making between developed and developing countries as commented by Harvman (1987) and Atory (2008). Between countries, the variations might largely depend on local requirements and suitability (Parsons, 1995; Leong, 1992). This research also noted that Malaysia has developed a certain "culture" of policy making. It seems the policy making process in Malaysia is very much linked to personality, individual, and autonomous administrative acts. The research also discovered for the need of organizations to improve the management, negotiation, and leadership skill of their staff, since the success of designing and developing a policy according to appropriate methods depends a lot on individual preference rather than team work. Apparently, the executive arm of the government who are mainly elected ministers and politicians have influence on the decisions of Malaysian civil servants and bureaucrats in the policy making process. Like- wise, the latter have shown the tendency to abide to their political masters and senior management in making decisions regarding policies. This fact is new as there is no literature review to indicate such culture amongst developed countries or elsewhere.

Even when there are involvement of stakeholders in the said processes, these are still limited, not widespread and done on selective basis. Although developed countries have already proven the importance of organizations to be more open and inclusive towards the involvement of stakeholders in the above process (Sabatier,1986; Van Meter \& Van Horn, 1975) the said practice is still not well received locally. Senior and seasoned policy makers are hesitant to change compared to young, fresh and mid-management policy makers. Apparently, policy as a field of study required special trained officers and personal, especially for negotiation and advocacy purposes. Without negotiation, advocacy or involvement of stakeholders, the effectiveness of the intended policy could be at risk in the long run. The public might not gauge or support the policy. If that happens, it would and could ultimately contribute towards policy failures.

\section{E. CONCLUSION}

This report is valuable in terms of its contribution towards policy studies in Malaysia. The studied data from the five organizations did confirm the big gap between theory and practice in the policy making process in Malaysia. The finding is not surprising considering policy studies and formal policy making process, according to the appropriate steps and cycles, are relatively new to policy makers and the society in general. It also revealed the point of gaps in a policy making process. Policy making process in Malaysia is very much based and determined by politics or politicians. Furthermore the decision is very much attached to individuals and personality. It also proves that the approach of developing policy by simply following established norm, peer or past experience would not necessarily produce the right or desired outcomes. Further studies on a larger scale is needed to confirm whether the above is common or just an isolated case. 
In all, there is a bright future for policy studies in Malaysia. The junior, fresh, and midmanagement policy makers should be given more opportunities and exposure to design, formulate and develop a policy appropriately according to the proper policy cycle. Seasoned and senior policy makers could also be given the opportunities to refresh their knowledge and skills in policy making process.

\section{REFERENCES}

Althaus, C., Bridgman, P., \& Glyn, D. (2017). Australian policy making handbook ( $7^{\text {th }} \mathrm{Ed}$.). Crows Nest, Australia: Allen \& Unwin.

Ansori, S. (2013). Policy formulation processes in Malaysia and Australia: Cultural differences do matter (Unpublished $\mathrm{PhD}$ thesis, Australian National University).

Ariffin, R. N. R. \& Mansor, N. (2009). The cabinet: Highest decision maker in the land. In A. R. Baginda (Ed.), Governing Malaysia (113-40). Kuala Lumpur: Malaysian Strategic Research Centre.

Ascher, W. (2017). Understanding policymaking process in developing countries. London: Cambridge University Press.

Atory, H. (2008). Pembentukanpolisi awam. Kuala Lumpur: Dewan Bahasa dan Pustaka.

Bari, A. A. (2009). The monarchy and state governing. In A. R. Baginda, Malaysian Strategic Research Centre (75-90). Kuala Lumpur: Malaysian Strategic Research Centre.

Bingham, R. D. \& Felbinger, C. L. (1989). Evaluation in practice: A methodological approach. New York: Longman.

Cascio, W. (1989). Human resource management. New York: Mcgraw Hill.

Churchill, Jr., G. A. (1991). Marketing research methodological foundations ( $5^{\text {th }}$ Ed.). Orlando, Florida: Dryden Press.

Esterberg, K. G. (2002). Qualitative methods in social research. New York, USA: McGraw Hill.

Friedman., L. (2002) Microeconomic policy analysis. Princeton, New Jersey: Princeton University Press.

Harvman, R. (1987). Policy evaluation research after 20 years. Policy Studies Journal, 191-218.

Howlett, M. \& Ramesh, M. (1995). Studying public policy: Policy cycles and policy subsystems, Oxford: Oxford University Press.

Gerston, L. N. (2010). Public policy making ( $3^{\text {rd }}$ Ed.). Armonk, New York: M.E. Sharpe.
Gicks, R. (2000). Practice issues for the beginning trainer. Boston: Allyn \& Bacon.

Leong, H. K. (1992). Dynamics of policy making in Malaysia: The formulation of the New economic policy and the national development policy. Asian Journal of Public Administration,14(2), 204-227, DOI: 10.1080/02598272.1992.10800269.

Malaysian Framework for Evaluation Policy And Standards. (2016). Evaluation for sustainability. Retrieved from https://www.evalpartners.org/sites/default/files/documents/ p2p/SGP15-10/MALAYSIAN\%20FRAMEWORK\%20FOR\%20EVALUATION\%20 POLICY\%20AND\%20STANDARDS $\% 20$ -\%20MyFEPS\%20-\%20Evaluation $\% 20$ for $\% 20$ Sustainability.pdf.

McCool, D. (1995). Public policy models and concepts: An anthology. New York: Prentice Hall.

Miles, M. B. \& Huberman, M. A. (1994). Qualitative data analysis: London: Sage Publications.

Muslihah, H. (2010). Policy making in Malaysia. Retrieved from www.vodppl.upm.edu.my/ uploads/docs/FEM3106\%20TOPIC\%202.ppt.

Parsons, W. (1995). Public policy: An introduction to the theory and practice of policy analysis. Cheltenham, UK: Edward Elgar Pub.

Poon, S. W. (1994). Pengurusan sumber manusia. Kuala Lumpur: Dewan Bahasa dan Pustaka.

Rahmah, Y. (2004) Peningkatan kualiti pengajaran polisi. In Prosiding persidangan antarabangsa pembangunan Aceh.

Ricks, B., Ginn, M. L., \& Daughtrey, A. S. (1995). Contemporary supervision ( $2^{\text {nd }}$ Ed.). New York: Mcgraw Hill, Inc.

Sabatier, P. (1986). Top down and bottom-up approaches to implementation research: A critical analysis and suggested synthesis. Journal of Public Policy, 6(1), 21-48.

Truelove, S. (1995). The handbook of training and development ( $2^{\text {nd }}$ Ed.). Oxford: Blackwell Bussiness.

Van Meter, D. S. \& Van Horn, C. E. (1975). The policy implementation process. Journal of Administration and Society, 6(4), 445-488. https://doi. org/10.1177/009539977500600404.

Whoky, J. S. (1970). Federal evaluation policy. Washington D.C.: The Urban Institute.

Yin, R. K. (1994). Case study research: Design and methods. Beverly Hills, CA: Sage Publications. 